Erschien zuerst in: Journal of Organometallic Chemistry 620 (2001) 165-173

\title{
Zwitterionic adducts from addition of imines to the $\alpha$-carbon atom of pentacarbonyl(vinylidene)chromium and -tungsten complexes
}

\author{
Helmut Fischer *, Frank Kirchbauer, Angelika Früh, Mokhles M. Abd-Elzaher ${ }^{1}$, \\ Gerhard Roth, Christoph C. Karl, Markus Dede
}

Fachbereich Chemie, Universität Konstanz, Fach M727, D-78457 Konstanz, Germany

Received 24 May 2000; received in revised form 15 September 2000; accepted 29 September 2000

\begin{abstract}
Imines, Im, such as $\mathrm{MeN}=\mathrm{C}(\mathrm{Ph}) \mathrm{H}$ (5), 2-methyl 4,5-dihydrothiazole (8a), 2-methyl 4,5-dihydrooxazole (8b) and $\mathrm{MeN}=\mathrm{C}(\mathrm{OMe}) \mathrm{Me}(\mathbf{1 3})$ add to the $\alpha$-carbon atom of the vinylidene ligand in $\left[(\mathrm{CO})_{5} \mathrm{Cr}=\mathrm{C}=\mathrm{CMe}_{2}\right](\mathbf{4})$ to give isolable zwitterionic adducts, $\left[(\mathrm{CO})_{5} \mathrm{Cr}^{-}-\mathrm{C}\left(=\mathrm{CMe}_{2}\right)\left(\mathrm{Im}^{+}\right)\right]$. The reaction of $\left[(\mathrm{CO})_{5} \mathrm{~W}=\mathrm{C}=\mathrm{CPh}_{2}\right](\mathbf{1 2})$ with 13 also yields an adduct, $\left[(\mathrm{CO})_{5} \mathrm{~W}^{-}-\right.$ $\left.\mathrm{C}\left(=\mathrm{CPh}_{2}\right)\{\mathrm{NMe}=\mathrm{C}(\mathrm{OMe}) \mathrm{Me}\}^{+}\right](\mathbf{1 5})$, whereas from the corresponding reaction of 4 with xanthylideneimine, $\mathrm{H}-\mathrm{N}=\mathrm{C}\left(\mathrm{C}_{6} \mathrm{H}_{4}\right)_{2} \mathrm{O}$ (16), a carbene complex, $\left[(\mathrm{CO})_{5} \mathrm{Cr}=\mathrm{C}(i-\mathrm{Pr})-\mathrm{N}=\mathrm{C}\left(\mathrm{C}_{6} \mathrm{H}_{4}\right)_{2} \mathrm{O}\right](\mathbf{1 7})$, is obtained. Complex 17 presumably is formed by initial addition of 16 to 4 and subsequently rapid rearrangement. In solution, the adduct $\left[(\mathrm{CO})_{5} \mathrm{Cr}^{-}-\mathrm{C}\left(=\mathrm{CMe}_{2}\right)(\mathrm{NMe}=\mathrm{C}(\mathrm{Ph}) \mathrm{H})^{+}\right](6)$ slowly cyclizes to form the 2-azetidin-1-ylidene complex $\left[(\mathrm{CO})_{5} \mathrm{Cr}=\mathrm{C}-\mathrm{NMe}-\mathrm{C}(\mathrm{Ph}) \mathrm{H}-\mathrm{CMe}{ }_{2}\right](7)$. In contrast, when solution of those zwitterions are heated that are formed by addition of 4,5-dihydrothiazole or 4,5-dihydrooxazole to 4, no cyclization is observed but rather the formation of 4,5-dihydrothiazole and 4,5-dihydrooxazole complexes, respectively. The structures of two adducts, $\left[(\mathrm{CO})_{5} \mathrm{Cr}^{-}-\mathrm{C}\left(=\mathrm{CMe}_{2}\right)\left(\mathrm{Im}^{+}\right)\right](\mathrm{Im}=\mathrm{MeN}=\mathrm{C}(\mathrm{Ph}) \mathrm{H}, 2$-methyl 4,5-dihydrothiazole $)$ and of the substitution product $\left[(\mathrm{CO})_{5} \mathrm{~W}(2-\right.$ methyl 4,5-dihydrothiazole)] have been established by X-ray structural analyses. (C) 2001 Elsevier Science B.V. All rights reserved.
\end{abstract}

Keywords: Pentacarbonyl(vinylidene) complexes; Imines; Adduct formation; 4,5-Dihydrothiazole complexes; Carbene complexes

\section{Introduction}

Vinylidene complexes react with imines by cycloaddition of the $\mathrm{C}=\mathrm{N}$ bond of the imine to the $\mathrm{C}=\mathrm{C}$ bond of the vinylidene complex to give four-membered transition metal substituted $N$-heterocycles (Scheme 1) [1-8].

Subsequent oxidative cleavage of the $\mathrm{M}=\mathrm{C}$ bond affords $\beta$-lactams. Very likely, the cycloaddition reac-

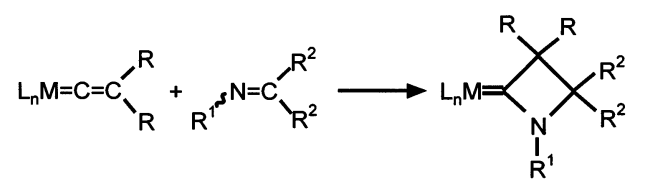

Scheme 1.

\footnotetext{
* Corresponding author. Tel.: +49-7531-882783; fax: +49-7531883136.

E-mail address: hfischer@dg6.chemie.uni-konstanz.de (H. Fischer).

${ }^{1}$ Present address: Inorganic Chemistry Department, National Research Centre, PO 12622 Dokki, Cairo, Egypt.
}

tion proceeds in a stepwise fashion. Addition of the imine via the lone electron pair at nitrogen to the $\alpha$-carbon atom of the vinylidene ligand to form a zwitterion is followed by ring-closure of the intermediate to give the cyclic ligand. Such a mechanistic scheme is corroborated by the observation of a zwitterionic cation $\left\{\mathrm{Cp}\left[\mathrm{P}(\mathrm{OMe})_{3}\right](\mathrm{CO}) \mathrm{Fe}-\mathrm{C}\left(=\mathrm{CMe}_{2}\right) \mathrm{NMe}=\mathrm{CH}-\right.$ $\mathrm{Ph}\}^{+}$(1) in the reaction of $\left\{\mathrm{Cp}\left[\mathrm{P}(\mathrm{OMe})_{3}\right](\mathrm{CO}) \mathrm{Fe}=\mathrm{C}=\right.$ $\left.\mathrm{CMe}_{2}\right\}^{+}$with $\mathrm{MeN}=\mathrm{C}(\mathrm{H}) \mathrm{Ph}$ in 1,2-dichloroethane [1,2]. Complex 1 was characterized by IR and ${ }^{1} \mathrm{H}-\mathrm{NMR}$ spectroscopy. On standing in solution, 1 underwent cyclization to produce the corresponding 2-azetidin-1ylidene complex.

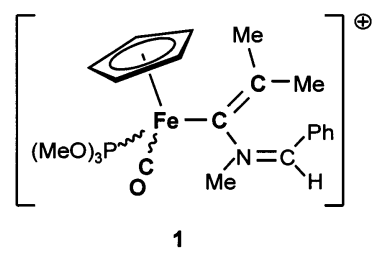




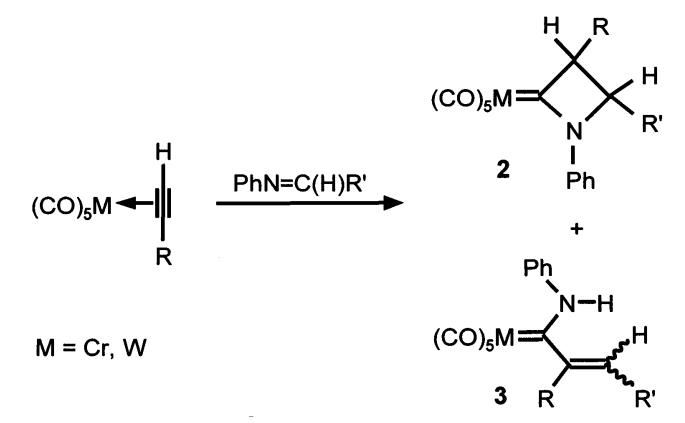

Scheme 2.

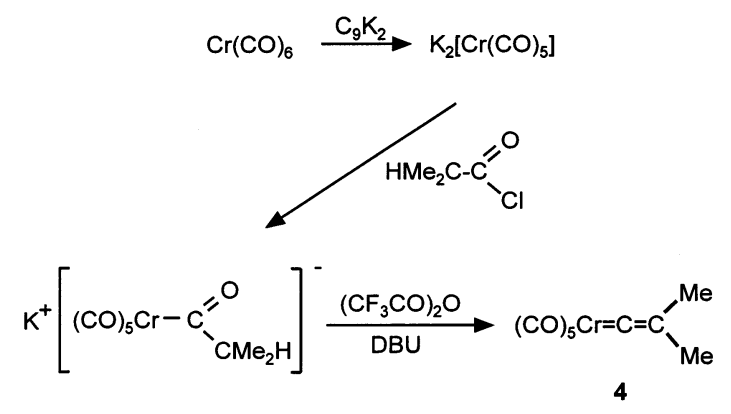

Scheme 3.

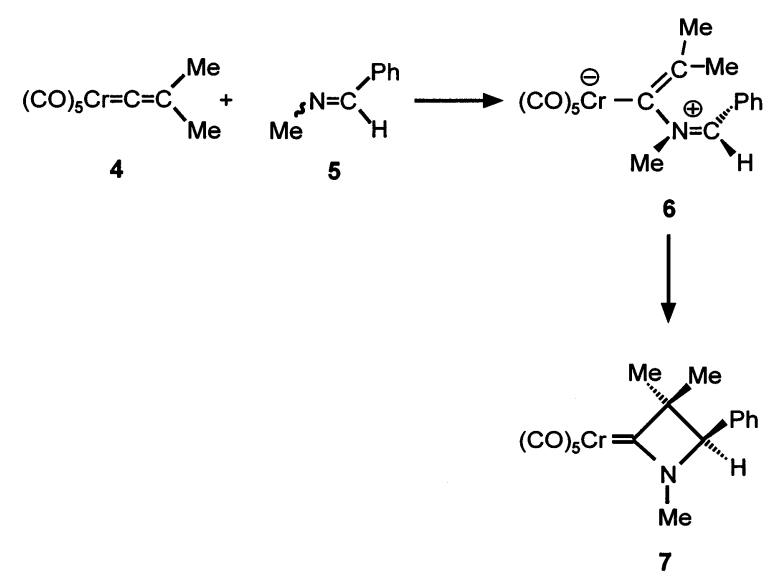

Scheme 4.

We recently observed that in the reaction of $\left[(\mathrm{CO})_{5} \mathrm{M}=\mathrm{C}=\mathrm{C}(\mathrm{H}) \mathrm{R}\right](\mathrm{M}=\mathrm{Cr}, \mathrm{W} ; \mathrm{R}=$ aryl $)$ generated by tautomerization of the alkyne complexes $\left[(\mathrm{CO})_{5} \mathrm{M}(\mathrm{HC} \equiv \mathrm{CR})\right]$ with $N$-aryl benzylideneamines two types of complexes are formed: 2-azetidin-1-ylidene complexes (2) and alkenyl(amino)carbene complexes (3) (Scheme 2).

Mechanistic experiments established that the alkenyl(amino)carbene complexes $\mathbf{3}$ are not derived from the 2-azetidin-1-ylidene complexes 2 [8]. In contrast to $\mathrm{N}$ aryl imines, alkenyl(amino)carbene complexes were not found among the products of the reaction of $N$-alkyl imines with $\left[(\mathrm{CO})_{5} \mathrm{M}=\mathrm{C}=\mathrm{C}(\mathrm{H}) \mathrm{R}\right]$ [7]. Zwitterionic intermediates were not detected, neither in the reactions of
$\left[(\mathrm{CO})_{5} \mathrm{M}=\mathrm{C}=\mathrm{C}(\mathrm{H}) \mathrm{R}\right]$ with $N$-aryl imines nor in that with $N$-alkyl imines. To get more information on the initial step of the reactions of pentacarbonyl vinylidene complexes with imines we studied the reactions of $\left[(\mathrm{CO})_{5} \mathrm{Cr}=\mathrm{C}=\mathrm{CMe}_{2}\right]$ with various cyclic and acyclic imines.

\section{Results and discussion}

The starting vinylidene complex $\left[(\mathrm{CO})_{5} \mathrm{Cr}=\mathrm{C}=\mathrm{CMe}_{2}\right]$ (4) [9] was generated by the reaction sequence shown in Scheme 3. Reduction of $\left[\mathrm{Cr}(\mathrm{CO})_{6}\right]$ with potassiumgraphite $\left(\mathrm{C}_{9} \mathrm{~K}_{2}\right)$ laminate in $\mathrm{THF}$ at $0^{\circ} \mathrm{C}$ gave $\mathrm{K}_{2}\left[\mathrm{Cr}(\mathrm{CO})_{5}\right]$ [10]. Subsequent reaction with isobutyryl chloride afforded potassium pentacarbonyl(isobutyryl)chromate which was then transformed into $\mathbf{4}$ by reaction with trifluoroacetic acid anhydride in $\mathrm{CH}_{2} \mathrm{Cl}_{2}$ at $-78^{\circ} \mathrm{C}$ [11]. Complex 4 is unstable and rapidly decomposes in solution at room temperature. Therefore, $\mathbf{4}$ was not isolated but only characterized by its $v(\mathrm{CO})$ spectrum. The solutions of $\mathbf{4}$ were then immediately employed for the reactions with imines.

When one equivalent of $N$-methyl benzylideneamine (5) was added to a solution of $\mathbf{4}$ in pentane $-\mathrm{CH}_{2} \mathrm{Cl}_{2}$ (ca. 1:1) at $-45^{\circ} \mathrm{C}$ the initially green solution immediately turned red. Addition of a tenfold excess of pentane led to precipitation of the complex 6 in the form of red crystals (Scheme 4). The zwitterionic iron complex $\left\{\mathrm{Cp}\left[\mathrm{P}(\mathrm{OMe})_{3}\right](\mathrm{CO}) \mathrm{Fe}-\mathrm{C}\left(=\mathrm{CMe}_{2}\right) \mathrm{NMe}=\mathrm{CHPh}\right\}^{+}$ $\left[\mathrm{CF}_{3} \mathrm{SO}_{3}\right]^{-}$could be isolated by chromatography [1]. In contrast, attempted chromatography of $\mathbf{6}$ only led to decomposition of the complex. Therefore, $\mathbf{6}$ had to be purified by recrystallization from diethyl ether.

Complex 6 is only poorly soluble in unpolar solvents but readily soluble in polar solvents such as $\mathrm{CH}_{2} \mathrm{Cl}_{2}$. In the solid state, $\mathbf{6}$ is stable at room temperature.

The mass spectrum of $\mathbf{6}$ established its composition as a 1:1 complex of $\mathbf{4}$ and $\mathbf{5}$. The proposal of a zwitterionic constitution of $\mathbf{6}$ as shown in Scheme 4 rather than of an 2-azetidin-1-ylidene complex structure (7 in Scheme 4) is based on several spectroscopic observations:

1. The $v(\mathrm{CO})$ absorptions are at rather low wave numbers indicative of a considerable electron transfer from the ligand to the $(\mathrm{CO})_{5} \mathrm{Cr}$ fragment. The $v(\mathrm{CO})$ absorptions of a 2-azetidin-1-ylidene complex like 7 are expected at higher wave numbers (vide infra).

2. The UV-vis spectrum of $\mathbf{6}$ exhibits a pronounced negative solvatochromic effect when nonpolar pentane is replaced by polar DMF in accord with a dipolar constitution. The UV-vis absorption at lowest energy in pentane is at $568 \mathrm{~nm}$, however, at $452 \mathrm{~nm}$ in DMF $\left[\Delta v(\right.$ pentane-DMF $\left.)=4520 \mathrm{~cm}^{-1}\right]$. 
3. The ${ }^{1} \mathrm{H}-\mathrm{NMR}$ spectrum shows in addition to three singlets for the inequivalent methyl groups and the multiplet for the phenyl hydrogens a singlet at low field $(\delta$ 7.82) for the benzylidene hydrogen atom. From the observation of only one set of methyl resonances it follows that predominantly one isomer with respect to the $\mathrm{N}=\mathrm{C}$ bond is formed (ratio of isomers $>9: 1)$.

4. The resonance of the chromium-bound carbon atom of the cyclic ligand in 2-azetidin-1-ylidene(pentacarbonyl)chromium complexes is usually observed in between $\delta=285$ and $300 \mathrm{ppm}[7,8]$. A peak in this range in the ${ }^{13} \mathrm{C}$-NMR spectrum of 6 is absent. The signals at lowest field are those of the $\mathrm{CO}$ ligands at $\delta=223.29$ (trans) and 219.34 (cis).

The zwitterionic constitution of 6 was additionally confirmed by the results of an X-ray structural analysis (Fig. 1, Table 1). Suitable crystals for an X-ray analysis were obtained by recrystallization of $\mathbf{6}$ from

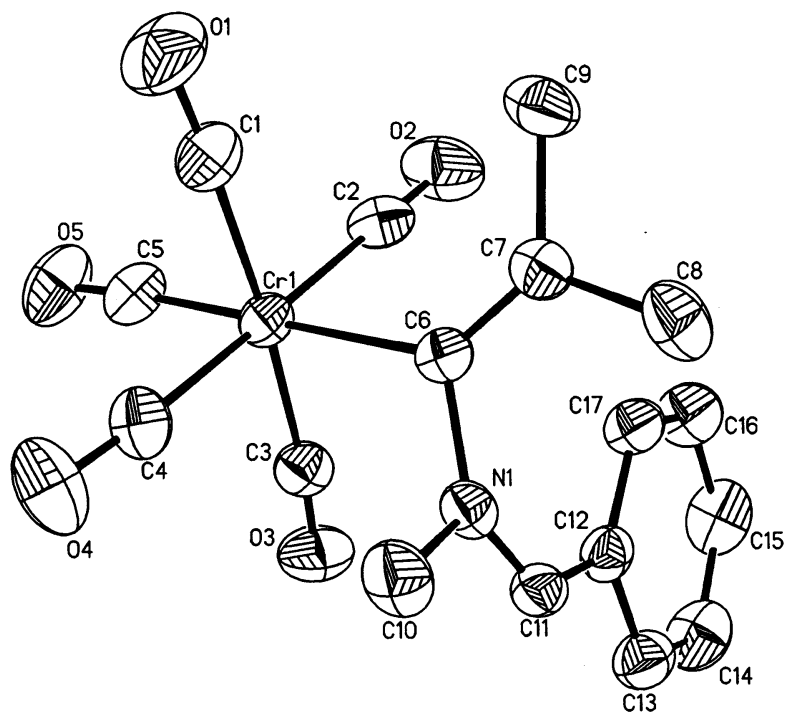

Fig. 1. Molecular structure of complex 6 in the crystal (hydrogen atoms are omitted for clarity). Selected torsion angles $\left({ }^{\circ}\right)$ are: $\mathrm{C}(2)-$ $\mathrm{Cr}(1)-\mathrm{C}(6)-\mathrm{C}(7)$ 54.5(3), N(1) $-\mathrm{C}(6)-\mathrm{C}(7)-\mathrm{C}(8) 2.1(4), \mathrm{C}(7)-\mathrm{C}(6)-$ $\mathrm{N}(1)-\mathrm{C}(10)$ 87.6(3), C(6)-N(1)-C(11)-C(12) 1.5(3).

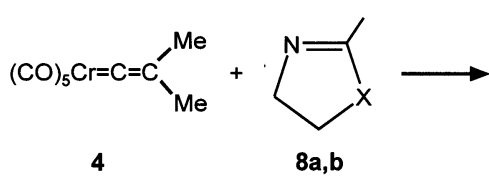

$X=S(a), O(b)$
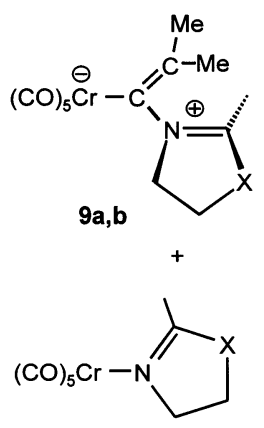

$10 a, b$ dichloromethane. The most prominent feature of the structure of $\mathbf{6}$ is the almost perpendicular arrangement of the vinylidene plane formed by the atoms $\operatorname{Cr}(1)$, $\mathrm{C}(6), \mathrm{C}(7), \mathrm{C}(8)$, and $\mathrm{C}(9)$ and the imine plane $[\mathrm{N}(1)$, $\mathrm{C}(6), \mathrm{C}(10), \mathrm{C}(11), \mathrm{C}(12)$ ]. The torsion angle $\mathrm{C}(7)$ $\mathrm{C}(6)-\mathrm{N}(1)-\mathrm{C}(10)$ is $87.6(3)^{\circ}$. Thus, the formation of an extended $\pi$-system involving the planar coordinated atoms $\mathrm{C}(6), \mathrm{C}(7)$, and $\mathrm{N}(1)$ [sum of angles $360.0^{\circ}$ at $\mathrm{C}(6), 359.8^{\circ}$ at $\mathrm{C}(7)$ and $360^{\circ}$ at $\mathrm{N}(1)$ ] is prevented. As a consequence, the $\mathrm{N}(1)-\mathrm{C}(11)$ bond $[1.286(3) \AA]$ is short and corresponds to a typical $\mathrm{N}=\mathrm{C}\left(\mathrm{sp}^{2}\right)$ double bond [12]. Both $\mathrm{N}-\mathrm{C}$ single bonds, $\mathrm{N}(1)-\mathrm{C}(6)\left(\mathrm{sp}^{2}\right)$ and $\mathrm{N}(1)-\mathrm{C}(10)\left(\mathrm{sp}^{3}\right)$, are equal in length indicating that the $\mathrm{N}(1)-\mathrm{C}(6)$ bond is rather weak. The $\mathrm{Cr}(1)-\mathrm{C}(6)$ distance $[2.191(2) \AA]$ is longer than that usually observed for chromium alkoxycarbene or aminocarbene complexes [13] indicating that the $\mathrm{C}\left(=\mathrm{CMe}_{2}\right)_{-}$ $\mathrm{NMe}=\mathrm{C}(\mathrm{Ph}) \mathrm{H}$ ligand exhibits only poor $\pi$-acceptor properties. In accord with such a conclusion, a pronounced trans influence is observed: the $\mathrm{Cr}-\mathrm{CO}$ (trans) bond $[1.840(2) \AA]$ is significantly shorter than the average of the $\mathrm{Cr}-\mathrm{CO}($ cis $)$ bonds $\left[\begin{array}{lll}1.892 & \AA\end{array}\right]$. To avoid unfavorable steric interactions the $\mathrm{C}\left(=\mathrm{CMe}_{2}\right) \mathrm{N}$ plane bisects the adjacent $\mathrm{OC}-\mathrm{Cr}-\mathrm{CO}$ angle [torsion angle $\left.\mathrm{C}(2)-\mathrm{Cr}(1)-\mathrm{C}(6)-\mathrm{C}(7) 54.5(3)^{\circ}\right]$.

In 1.1.2-trichloroethane complex 6 slowly formed the 2-azetidin-1-ylidene complex 7 (Scheme 4). At room temperature the reaction was complete after about 1 week. The cyclization rate increased with increasing polarity of the solvent and with increasing temperature. Thus, in methanol or ethanol the reaction was already complete within about 1 day and in butyl vinyl ether at $60^{\circ} \mathrm{C}$ after ca. $5 \mathrm{~h}$. Chromatographic workup afforded complex 7 in ca. $45 \%$ yield.

The cyclization is accompanied by a shift of the $v(\mathrm{CO})$ absorptions toward higher frequencies. Indicative for the formation of the carbene (2-azetidin-1-ylidene) complex 7 is the resonance of the carbene carbon atom at $\delta=295.42 \mathrm{ppm}$. In general, the ${ }^{1} \mathrm{H}$ - and ${ }^{13} \mathrm{C}$ NMR resonances of 7 are comparable to those of the 2-azetidin-1-ylidene chromium complexes reported earlier $[7,8]$.

Analogously to 5, the addition of 2-methyl 4,5-dihydrothiazole (8a) to a solution of $\mathbf{4}$ led to an immediate color change from green to yellow. However, contrary to the reaction of $\mathbf{4}$ with $\mathbf{5}$, the workup of the reaction mixture afforded two complexes, the adduct 9a and the substitution product 10a (Scheme 5). The adduct 9a constituted the major product.

The $v(\mathrm{CO})$ absorptions of $9 \mathbf{a}$ are shifted to smaller wave numbers relative to those of 6 by ca. $2-5 \mathrm{~cm}^{-1}$ indicating slightly increased donor properties of $\mathbf{8 a}$ as compared with those of 5 . The ${ }^{13} \mathrm{C}$-NMR resonances of structurally comparable atoms in $\mathbf{6}$ and $\mathbf{9 a}$ are observed at similar positions. The ring hydrogen atoms are diastereotopic giving rise to two well-separated groups

Scheme 5. 


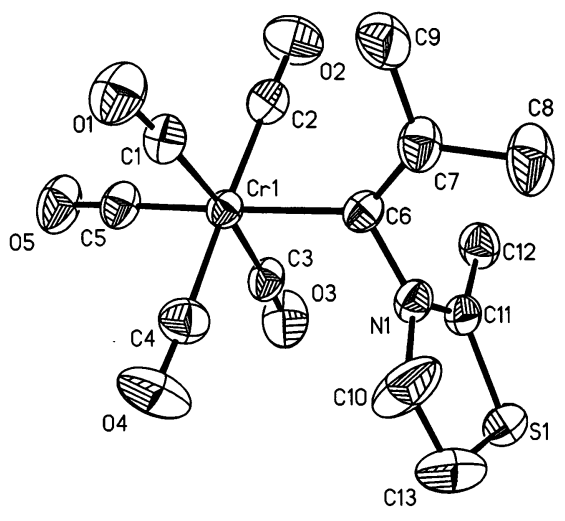

Fig. 2. Molecular structure of complex 9a in the crystal (hydrogen atoms are omitted for clarity). Selected torsion angles $\left({ }^{\circ}\right)$ are: $\mathrm{C}(2)-$ $\mathrm{Cr}(1)-\mathrm{C}(6)-\mathrm{C}(7)$ 51.4(4), $\mathrm{N}(1)-\mathrm{C}(6)-\mathrm{C}(7)-\mathrm{C}(8) 3.2(5), \mathrm{C}(7)-\mathrm{C}(6)-$ $\mathrm{N}(1)-\mathrm{C}(10) \quad 93.6(5), \quad \mathrm{C}(11)-\mathrm{N}(1)-\mathrm{C}(10)-\mathrm{C}(13) \quad-7.5(8)$, $\mathrm{S}(1)-\mathrm{C}(13)-\mathrm{C}(10)-\mathrm{N}(1) 7.7(7)$.

Table 1

Selected bond lengths $(\AA)$ and bond angles $\left({ }^{\circ}\right)$ for $\mathbf{6}$ and 9a

\begin{tabular}{lll}
\hline & $\mathbf{6}$ & $\mathbf{9 a}$ \\
\hline Bond lengths & & \\
$\mathrm{Cr}(1)-\mathrm{C}(1)$ & $1.905(2)$ & $1.878(4)$ \\
$\mathrm{Cr}(1)-\mathrm{C}(2)$ & $1.909(3)$ & $1.894(4)$ \\
$\mathrm{Cr}(1)-\mathrm{C}(3)$ & $1.878(2)$ & $1.887(4)$ \\
$\mathrm{Cr}(1)-\mathrm{C}(4)$ & $1.873(3)$ & $1.869(5)$ \\
$\mathrm{Cr}(1)-\mathrm{C}(5)$ & $1.840(2)$ & $1.847(5)$ \\
$\mathrm{Cr}(1)-\mathrm{C}(6)$ & $2.191(2)$ & $2.170(5)$ \\
$\mathrm{C}(6)-\mathrm{C}(7)$ & $1.335(3)$ & $1.349(6)$ \\
$\mathrm{C}(6)-\mathrm{N}(1)$ & $1.475(3)$ & $1.469(6)$ \\
$\mathrm{C}(7)-\mathrm{C}(8)$ & $1.513(3)$ & $1.488(8)$ \\
$\mathrm{C}(7)-\mathrm{C}(9)$ & $1.511(4)$ & $1.522(8)$ \\
$\mathrm{N}(1)-\mathrm{C}(10)$ & $1.478(4)$ & $1.460(6)$ \\
$\mathrm{N}(1)-\mathrm{C}(11)$ & $1.286(3)$ & $1.286(5)$ \\
Bond angles & & \\
$\mathrm{Cr}(1)-\mathrm{C}(6)-\mathrm{C}(7)$ & $134.8(2)$ & $134.2(4)$ \\
$\mathrm{Cr}(1)-\mathrm{C}(6)-\mathrm{N}(1)$ & $112.8(1)$ & $113.3(3)$ \\
$\mathrm{N}(1)-\mathrm{C}(6)-\mathrm{C}(7)$ & $112.4(2)$ & $112.5(4)$ \\
$\mathrm{C}(6)-\mathrm{C}(7)-\mathrm{C}(8)$ & $125.4(2)$ & $122.6(5)$ \\
$\mathrm{C}(6)-\mathrm{C}(7)-\mathrm{C}(9)$ & $122.3(2)$ & $124.5(5)$ \\
$\mathrm{C}(6)-\mathrm{N}(1)-\mathrm{C}(10)$ & $115.4(2)$ & $119.4(3)$ \\
$\mathrm{C}(6)-\mathrm{N}(1)-\mathrm{C}(11)$ & $126.0(2)$ & $126.8(3)$ \\
$\mathrm{C}(10)-\mathrm{N}(1)-\mathrm{C}(11)$ & $118.7(2)$ & $113.8(4)$ \\
$\mathrm{N}(1)-\mathrm{C}(11)-\mathrm{C}(12)$ & $130.0(2)$ & $123.3(4)$ \\
$\mathrm{N}(1)-\mathrm{C}(11)-\mathrm{S}(1)$ & & $115.6(3)$ \\
\hline & &
\end{tabular}<smiles>CC(=O)ON=C(C)C(=O)ON1CCSC1=Cc1ccccc1</smiles>

Scheme 6.

of signals for the $\mathrm{NCH}_{2}$ protons $(\Delta \delta=0.59 \mathrm{ppm})$. The $\mathrm{SCH}_{2}$ protons appear as a triplet only. Analogously to $\mathbf{6}$, the imine plane and the vinylidene plane are almost perpendicular (Fig. 2). The torsion angle $\mathrm{C}(7)-\mathrm{C}(6)-$
$\mathrm{N}(1)-\mathrm{C}(10)$ in $9 \mathrm{a}$ is $93.6(5)^{\circ}$ as compared with $87.6(3)^{\circ}$ in 6. Within error limits the distances and angles within the $(\mathrm{CO})_{5} \mathrm{Cr}-\mathrm{C}\left(=\mathrm{CMe}_{2}\right) \mathrm{N}$ fragment are equal in $\mathbf{6}$ and 9a (Table 1). The 4,5-dihydrothiazole ring adopts an slight envelope conformation, the torsion angle $\mathrm{S}(1)$ $\mathrm{C}(13)-\mathrm{C}(10)-\mathrm{N}(1)$ is $7.7(7)^{\circ}$.

Complex 10a was characterized by IR and ${ }^{1} \mathrm{H}-\mathrm{NMR}$ spectroscopy only. The spectroscopic data are comparable to those of the corresponding tungsten complex (11) formed in the reaction of $\mathbf{8 a}$ with $\left[(\mathrm{CO})_{5} \mathrm{~W}=\mathrm{C}=\mathrm{C}(\mathrm{Ph}) \mathrm{H}\right]$ (Scheme 6) which in solution is in equilibrium with its alkyne tautomer $\left[(\mathrm{CO})_{5} \mathrm{~W}(\mathrm{Ph}-\right.$ $\mathrm{C} \equiv \mathrm{C}-\mathrm{H})][14]$.

Complex 11 was characterized fully including by an $\mathrm{X}$-ray structural analysis (Fig. 3). As expected, the $v(\mathrm{CO})$ absorptions of 10a and $\mathbf{1 1}$ are similar, however, are at significantly higher wave numbers than those of the adduct 9a $\left(\Delta v=15-28 \mathrm{~cm}^{-1}\right)$. From these shifts it follows that the $\mathrm{C}\left(=\mathrm{CMe}_{2}\right)(4,5$-dihydrothiazole) ligand transfers considerably more electron density to the $(\mathrm{CO})_{5} \mathrm{M}$ fragment than 4,5-dihydrothiazole which is in accord with the zwitterionic structure of $9 \mathbf{a}$.

In contrast to the 4,5-dihydrothiazole ring in 9a that in $\mathbf{1 1}$ is nearly planar. All torsion angles of the ring are smaller than $2^{\circ}$. The torsion angle $\mathrm{S}(1)-\mathrm{C}(7)-\mathrm{C}(6)-$ $\mathrm{N}(1)$ is $-1.6(13)^{\circ}$ as compared with $7.7(7)^{\circ}$ for the corresponding angle in 9a. As expected from steric considerations the plane of the ring bisects the adjacent $\mathrm{OC}-\mathrm{W}-\mathrm{CO}$ angle [torsion angle $\mathrm{C}(4)-\mathrm{W}(1)-\mathrm{N}(1)-$ $\left.\mathrm{C}(8) 49.7(7)^{\circ}\right]$. Due to the large standard deviations in 11 a detailed discussion and comparison of the distances and angles in the 4,5-dihydrothiazole ring in 9a and $\mathbf{1 1}$ is not feasible.

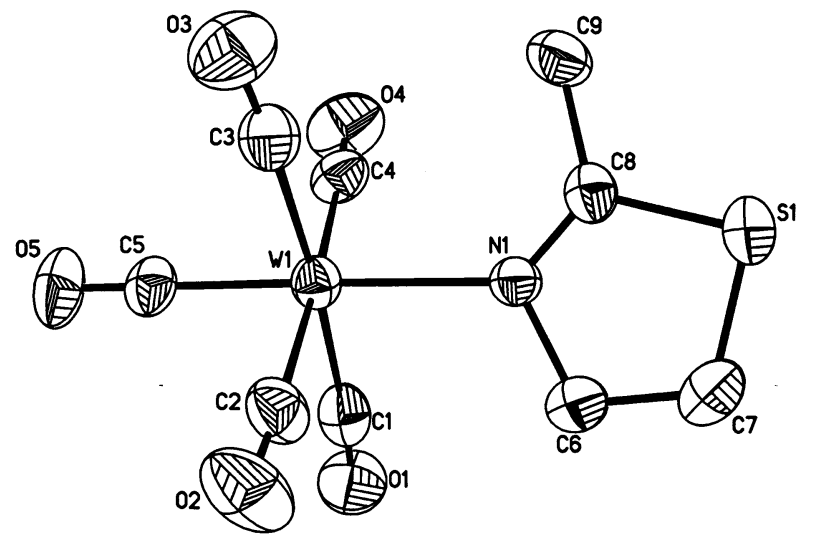

Fig. 3. Molecular structure of complex $\mathbf{1 1}$ in the crystal (hydrogen atoms are omitted for clarity). Selected bond lengths $(\AA)$ and bond angles $\left({ }^{\circ}\right)$ in 11 are: $\mathrm{W}(1)-\mathrm{C}(1) 2.056(10), \mathrm{W}(1)-\mathrm{C}(5)$ 1.992(8), W(1)$\mathrm{N}(1) 2.287(6), \mathrm{N}(1)-\mathrm{C}(6) 1.506(10), \mathrm{N}(1)-\mathrm{C}(8) 1.275(10), \mathrm{C}(6)-\mathrm{C}(7)$ $148.0(13) \quad \mathrm{C}(7)-\mathrm{S}(1) \quad 1.793(12), \quad \mathrm{C}(8)-\mathrm{S}(1) \quad 1.768(7), \quad \mathrm{C}(8)-\mathrm{C}(9)$ 1.504(11); $\quad \mathrm{W}(1)-\mathrm{N}(1)-\mathrm{C}(6) \quad 116.7(5), \quad \mathrm{W}(1)-\mathrm{N}(1)-\mathrm{C}(8) \quad 130.9(5)$, $\mathrm{C}(6)-\mathrm{N}(1)-\mathrm{C}(8) \quad 112.4(6), \mathrm{N}(1)-\mathrm{C}(6)-\mathrm{C}(67)$ 111.2(8), $\mathrm{C}(6)-\mathrm{C}(7)-$ $\mathrm{S}(1)$ 108.5(7), $\mathrm{C}(7)-\mathrm{S}(1)-\mathrm{C}(8)$ 90.7(4), $\mathrm{N}(1)-\mathrm{C}(8)-\mathrm{C}(9)$ 125.8(7), $\mathrm{N}(1)-\mathrm{C}(8)-\mathrm{S}(1) \quad 117.2(6), \quad \mathrm{C}(9)-\mathrm{C}(8)-\mathrm{S}(1) \quad 117.1(6) ; \quad \mathrm{C}(1)-\mathrm{W}(1)-$ $\mathrm{N}(1)-\mathrm{C}(8)$ 137.9(7). 


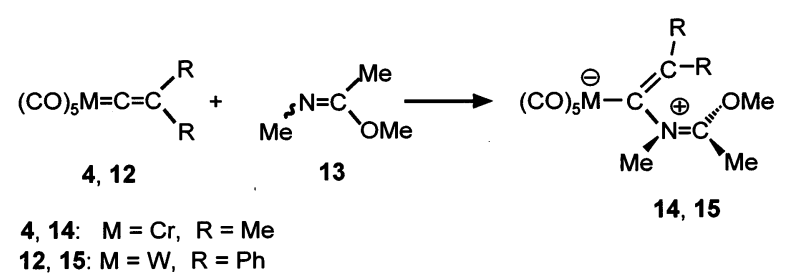

Scheme 7.

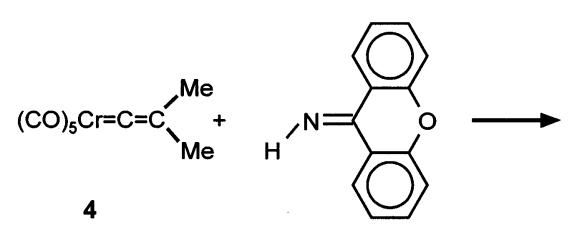

16

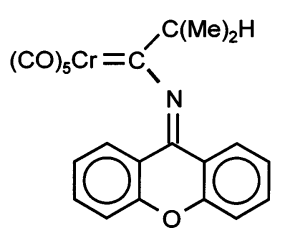

17
Scheme 8 .

Similarly to $\mathbf{8 a}$, the reaction of 2-methyl 4,5-dihydrooxazole $(\mathbf{8 b})$ with $\mathbf{4}$ afforded a mixture of predominantly the adduct (9b) and small amounts of the substitution product (10b) (Scheme 5). The IR and NMR spectra of $\mathbf{9 b}$ and $\mathbf{1 0 b}$ are similar to those of $\mathbf{9 a}$ and 10a, respectively, indicating similar structures.

In contrast to 6 and $\left\{\mathrm{Cp}\left[\mathrm{P}(\mathrm{OMe})_{3}\right](\mathrm{CO}) \mathrm{Fe}-\right.$ $\left.\mathrm{C}\left(=\mathrm{CMe}_{2}\right) \mathrm{NMe}=\mathrm{CHPh}\right\}^{+}$(1) $[1,2]$, when solution of the adducts $9 \mathbf{a}$ and $\mathbf{9 b}$ were kept at room temperature for days or were heated under reflux, no cyclization to give 2-azetidin-1-ylidene complexes but rather substitution and formation of the 4,5-dihydrothiazole and 4,5dihydrooxazole complexes 10a and 10b were observed.

Adducts $(\mathbf{1 4}, \mathbf{1 5})$ were also formed rapidly when $\mathrm{N}$-methyl 1-methoxyethylideneamine (13) was added to solutions of 4 or of $\left[(\mathrm{CO})_{5} \mathrm{~W}=\mathrm{C}=\mathrm{CPh}_{2}\right] \quad$ (12) [4] (Scheme 7).

The NMR spectra of $\mathbf{1 4}$ and $\mathbf{1 5}$ exhibit one set of resonances for the methyl groups of the former imine indicating that only one isomer (with respect to the $\mathrm{N}=\mathrm{C}$ bond) is formed. Again, the cyclization of the ligand in $\mathbf{1 4}$ and $\mathbf{1 5}$ to give 2-azetidin-1-ylidene complexes could not be induced.

In contrast, the products of the reactions of $N-\mathrm{H}$ imines with vinylidene complexes deviate from those of $N$-alkyl or $N$-aryl imines although the first reaction step is presumably analogous. When xanthylideneimine (16) was added to a solution of vinylidene complex 4 neither an adduct nor an 2-azetidin-1-ylidene complex was obtained. Instead, the isopropyl(xanthylideneamino)carbene complex $\mathbf{1 7}$ was isolated as the major product from the reaction mixture (Scheme 8).

The structure of $\mathbf{1 7}$ was deduced from the IR and NMR spectra. The $v(\mathrm{CO})$ spectrum of $\mathbf{1 7}$ is similar to that of other alkylideneaminocarbene complexes. The ${ }^{1} \mathrm{H}-\mathrm{NMR}$ spectrum exhibits a doublet and a heptet (intensity ratio 6:1) in addition to aromatic resonances for eight protons. In accord with an alkylideneaminocarbene complex constitution a low-field resonance at $\delta=225.45 \mathrm{ppm}$ for the carbene carbon atom is observed in the ${ }^{13} \mathrm{C}-\mathrm{NMR}$ spectrum [15].

Our results demonstrate that imines rapidly add to pentacarbonyl(vinylidene)metal complexes. However, the addition is reversible as has already been shown earlier [4]. Therefore, whether addition is succeeded by formation of a 2-azetidin-1-ylidene complex or not depends on the relative rates of cyclization and dissoziation of the imine (followed by decomposition of the resulting vinylidene complex). Cyclization and dissoziation may be regarded as competing reaction pathways. The dissociation is facilitated by a weak $C(\alpha)-N$ bond. Strongly electrophilic vinylidene complexes and strongly nucleophilic imines give rise to the formation of adducts stable with respect to dissociation. Then, cyclization clearly dominates as is observed with complex 6. The same is true for those imines employed in the reactions with pentacarbonyl(vinylidene) complexes reported earlier $[7,8]$.

Cyclization requires among others rotation around the $C(\alpha)-C(\beta)$ bond of the former vinylidene ligand, the $\mathrm{C}(\alpha)-\mathrm{N}$ and the $\mathrm{N}=\mathrm{C}$ bond. Therefore, steric factors in determining the rate of ring formation cannot be discarded. However, the failure of $\mathbf{9 a}$ and $\mathbf{9 b}$ to form 2-azetidin-1-ylidene complexes is very likely not due to steric reasons since cationic $\left\{\mathrm{Cp}\left[\mathrm{P}(\mathrm{OMe})_{3}\right](\mathrm{CO})\right.$ $\left.\mathrm{Fe}=\mathrm{C}=\mathrm{CMe}_{2}\right\}^{+}$has been reported to react with 2methyl 4,5-dihydrothiazole by cycloaddition to give the corresponding 2-azetidin-1-ylidene complex [2]. In contrast, the bonding of $\mathbf{8 a}$ to the vinylidene ligand in neutral pentacarbonyl(vinylidene) complexes such as $\mathbf{4}$ is expected to be weaker than in $\left\{\mathrm{Cp}\left[\mathrm{P}(\mathrm{OMe})_{3}\right](\mathrm{CO})\right.$ $\left.\mathrm{Fe}=\mathrm{C}=\mathrm{CMe}_{2}\right\}^{+}$. Presumably, at room temperature or at elevated temperatures dissociation of the imine from the zwitterions $\mathbf{9 a}, \mathbf{b}, \mathbf{1 4}$, and $\mathbf{1 5}$ is faster than cyclization. The resulting vinylidene complex is labile and quickly decomposes by elimination of the vinylidene ligand and addition of the imine to form pentacarbonyl(imine)metal complexes.

The reactions of $N$-unsubstituted imines with pentacarbonyl(vinylidene) complexes take a different course although the initial step in the reaction of $\mathbf{4}$ with xanthylideneimine presumably also involves addition of imine to the $\alpha$-carbon atom of the vinylidene ligand. The adduct then rapidly rearranges to form $\mathbf{1 7}$ either by migration of hydrogen from nitrogen to the $\beta$-carbon atom of the former vinylidene ligand or, more likely, by a deprotonation/reprotonation sequence. 


\section{Experimental}

\subsection{General}

All operations were performed under an inert atmosphere (nitrogen or argon) by using standard Schlenk techniques. Solvents were dried by refluxing over $\mathrm{CaH}_{2}$ $\left(\mathrm{CH}_{2} \mathrm{Cl}_{2}\right.$, pentane) or sodium-benzophenone ketyl $\left(\mathrm{Et}_{2} \mathrm{O}\right)$ and were freshly distilled under argon prior to use. The silica gel used for chromatography (Baker, silica gel for flash chromatography) was nitrogen saturated. The yields refer to analytically pure compounds and were not optimized. Instrumentation: ${ }^{1} \mathrm{H}$ - and ${ }^{13} \mathrm{C}$ NMR spectra were recorded with a Bruker AC 250 or a Bruker WM 250 spectrometer. ${ }^{1} \mathrm{H}-\mathrm{NMR}$ resonances are reported relative to $\mathrm{Me}_{4} \mathrm{Si},{ }^{13} \mathrm{C}$-NMR resonances relative to the residual solvent peaks of acetone- $d_{6}$. Unless mentioned specifically IR and NMR spectra are taken at room temperature (r.t.). IR: Biorad FTS 60 spectrophotometer; MS: Finnigan MAT 312 (EI, 70 eV). Elemental analyses: Heraeus CHN-O-RAPID. The complex 12 [4] and the imine 13 [16] were prepared according to literature procedures. All other imines were commercially available and were used without further purification.

\subsection{Generation of \\ pentacarbonyl[dimethylvinylidene]chromium (4)}

A suspension of $2.54 \mathrm{~g}(13.6 \mathrm{mmol})$ of $\mathrm{C}_{9} \mathrm{~K}_{2}$ in $50 \mathrm{ml}$ of THF is charged at $-78^{\circ} \mathrm{C}$ with $1.5 \mathrm{~g}(6.8 \mathrm{mmol})$ of chromium hexacarbonyl and stirred for $15 \mathrm{~min}$. The suspension is warmed to $0^{\circ} \mathrm{C}$. Within ca. $10 \mathrm{~min}$ the color changes from bronze to green and the evolution of a gas is detectable. After a total of ca. $90 \mathrm{~min}$ the formation of pentacarbonylchromate is complete. The green suspension is cooled to $-78^{\circ} \mathrm{C}$ and $0.72 \mathrm{ml}(6.8$ $\mathrm{mmol}$ ) of isobutyryl chloride is added. The color immediately changes to olive-green [IR (THF): $v(\mathrm{CO})$ $\left.\left(\mathrm{cm}^{-1}\right): 2031 \mathrm{~s}, 1892 \mathrm{vs}\right]$. After $5 \mathrm{~min}$ the temperature of the suspension is allowed to rise to $0^{\circ} \mathrm{C}$. The solvent is removed in vacuo at $0^{\circ} \mathrm{C}$ and the black-green residue is treated with $75 \mathrm{ml}$ of $\mathrm{CH}_{2} \mathrm{Cl}_{2}$. The suspension is cooled to $-78^{\circ} \mathrm{C}$ and, after addition of $0.54 \mathrm{ml}(3.4 \mathrm{mmol})$ of trifluoroacetic acid, stirred for $1 \mathrm{~h} .75 \mathrm{ml}$ of pentane precooled to $-78^{\circ} \mathrm{C}$ is added. The reaction mixture is fritted over a $6-\mathrm{cm}$ layer of $\mathrm{Al}_{2} \mathrm{O}_{3}$ at $-45^{\circ} \mathrm{C}$. The stationary phase is eluted with cold pentane- $-\mathrm{CH}_{2} \mathrm{Cl}_{2}$ $(1: 2)$ until the dark-green band is eluted completely. At $-45^{\circ} \mathrm{C}$, the solvent of the combined eluates [4: IR $\left(\mathrm{CH}_{2} \mathrm{Cl}_{2}\right): v(\mathrm{CO})\left(\mathrm{cm}^{-1}\right): 2082 \mathrm{~s}, 2025 \mathrm{sh}, 1998 \mathrm{vs}, 1971$ vs] is reduced in vacuo to a volume of ca. $20 \mathrm{ml}$. These solutions are employed for the subsequent reactions with imines. The yields of $\left[(\mathrm{CO})_{5} \mathrm{Cr}=\mathrm{C}=\mathrm{CMe}_{2}\right](4)$ are between 60 and $65 \%$ (determined by trapping experiments with bis- $N, N$-diethylaminopropyne).

\subsection{Pentacarbonyl\{2-methyl-1-[N-methyl-N- benzylideneaminium]-1-propenyl\}chromate (6)}

At $-45^{\circ} \mathrm{C}, 0.65 \mathrm{ml}(5 \mathrm{mmol})$ of $N$-methyl benzylideneamine (5) is added to a solution of $\left[(\mathrm{CO})_{5} \mathrm{Cr}=\mathrm{C}=\right.$ $\mathrm{CMe}_{2}$ ] (4) freshly prepared as described above from 2.1 $\mathrm{g}(9.5 \mathrm{mmol})$ of $\left[\mathrm{Cr}(\mathrm{CO})_{6}\right], 3.54 \mathrm{~g}(19 \mathrm{mmol})$ of $\mathrm{C}_{9} \mathrm{~K}_{2}$ and $1 \mathrm{ml}$ of isobutyryl chloride $(9.5 \mathrm{mmol})$ and concentrated to a volume of ca. $20 \mathrm{ml}$. The solution immediately turns red. After stirring the solution for $15 \mathrm{~min}$, it is allowed to warm to room temperature. Stirring is continued for $1 \mathrm{~h}$, the volume of the solution reduced in vacuo to 10 and $100 \mathrm{ml}$ of pentane is added. A red precipitate forms. The suspension is kept at $-20^{\circ} \mathrm{C}$ for $24 \mathrm{~h}$ and then fritted at room temperature (r.t.) through a 2-cm layer of neutral alumina. The red solid on top of the $\mathrm{Al}_{2} \mathrm{O}_{3}$ layer is washed with $100 \mathrm{ml}$ of pentane and subsequently dissolved in $150 \mathrm{ml}$ of $\mathrm{CH}_{2} \mathrm{Cl}_{2}$. The solvent is removed in vacuo and the residue dissolved in $20 \mathrm{ml}$ of diethyl ether. The solution is kept at $-20^{\circ} \mathrm{C}$ for $24 \mathrm{~h}$ and then filtered at $-18^{\circ} \mathrm{C}$ over a 6 -cm layer of sand-glass wool-sand. The layer is eluted with 20 $\mathrm{ml}$ of precooled diethyl ether. The solvent is removed in vacuo to yield 6 as a red solid. Yield: $790 \mathrm{mg}(23 \%$ relative to $\left.\left[\mathrm{Cr}(\mathrm{CO})_{6}\right]\right)$. M.p. $73^{\circ} \mathrm{C}$. IR $\left(\mathrm{CH}_{2} \mathrm{Cl}_{2}\right) v(\mathrm{CO})$ $\left(\mathrm{cm}^{-1}\right): 2044 \mathrm{~m}, 1960 \mathrm{~m}, 1917$ vs, 1910 vs. ${ }^{1} \mathrm{H}-\mathrm{NMR}$ $\left(\mathrm{CDCl}_{3}\right): \delta 1.48\left(\mathrm{~s}, 3 \mathrm{H}, \mathrm{CCH}_{3}\right), 2.02\left(\mathrm{~s}, 3 \mathrm{H}, \mathrm{CCH}_{3}\right)$, $3.85\left(\mathrm{~s}, 3 \mathrm{H}, \mathrm{NCH}_{3}\right), 7.5-7.7(\mathrm{~m}, 3 \mathrm{H}, \mathrm{Ph}), 7.82(\mathrm{~s}, 1 \mathrm{H}$, $\mathrm{N}=\mathrm{CH}$ ), 8.01-8.04 (pseudo- $d, J=7.5 \mathrm{~Hz}, 2 \mathrm{H}, \mathrm{Ph}$ ). ${ }^{13} \mathrm{C}$-NMR $\left(\mathrm{CDCl}_{3}\right.$, for the numbering scheme see Fig. 1): $\delta 19.09[\mathrm{C}(8)], 24.14[\mathrm{C}(9)], 50.68[\mathrm{C}(10)], 126.54$, $128.70,129.04,129.14,132.62,133.07[\mathrm{Ph}], 135.13$, $153.90[\mathrm{C}(6), \mathrm{C}(7)], 169.97$ [C(11)], 219.34 [cis-CO], 223.29 [trans-CO]. UV-vis $(\mathrm{nm})$ [solvent] $\lambda_{\max }(\log \varepsilon)$ : [pentane] 568 (2.996), [DMF] 452 (3.045). MS $m / z(\%)$ : 365 (5) $\left[\mathrm{M}^{+}\right], 309$ (2) $\left[\mathrm{M}^{+}-2 \mathrm{CO}\right], 281$ (4) $\left[\mathrm{M}^{+}-\right.$ $3 \mathrm{CO}$, 253 (10) $\left[\mathrm{M}^{+}-4 \mathrm{CO}\right.$, 246 (3) $\left[\mathrm{M}^{+}-N\right.$-methyl benzylideneamine], 225 (44) $\left[\mathrm{M}^{+}-5 \mathrm{CO}\right.$. Anal. Found: C, 56.38; H, 4.27; N, 4.03. $\mathrm{C}_{17} \mathrm{H}_{15} \mathrm{CrNO}_{5}$ (365.17). Calc.: C, 55.89; H, 4.14; N, 3.83\%.

\subsection{Pentacarbonyl[(N-methyl-3-phenyl-4,4- dimethylazetidin-2-ylidene]chromium (7)}

A solution of $240 \mathrm{mg}(6.6 \mathrm{mmol})$ of 6 in $12 \mathrm{ml}$ of butyl vinyl ether is heated at $50^{\circ} \mathrm{C}$ for $3 \mathrm{~h}$. The solvent is removed in vacuo and the brown residue is chromatographed at $-20^{\circ} \mathrm{C}$ on flash silica with pentane$\mathrm{CH}_{2} \mathrm{Cl}_{2}$ mixtures (ratio decreasing from 1:0 to 9:1). The first yellow band is collected. Removal of the solvent in vacuo affords complex 7 as a yellow solid. Yield: 110 $\mathrm{mg}(45 \%$ relative to 6$)$. M.p. $33^{\circ} \mathrm{C}$. IR (pentane) $v(\mathrm{CO})$ $\left(\mathrm{cm}^{-1}\right): 2056 \mathrm{~m}, 1969$ w, 1942 vs, 1925 s. ${ }^{1} \mathrm{H}-\mathrm{NMR}$ $\left(\mathrm{CD}_{3} \mathrm{COCD}_{3}\right): \delta 0.84$ and $1.46\left(2 \mathrm{~s}, 3 \mathrm{H}\right.$ each, $\left.\mathrm{CCH}_{3}\right)$, $3.52\left(\mathrm{~s}, 3 \mathrm{H}, \mathrm{NCH}_{3}\right), 3.53(\mathrm{~s}, 1 \mathrm{H}, \mathrm{CCH}), 7.19-7.50(\mathrm{~m}$, $5 \mathrm{H}, \mathrm{Ph}) .{ }^{13} \mathrm{C}-\mathrm{NMR}\left(\mathrm{CDCl}_{3}\right): \delta 19.44,24.16\left[\mathrm{CCH}_{3}\right]$, 
$36.62\left[\mathrm{NCH}_{3}\right], 58.9\left[\mathrm{CMe}_{2}\right], 84.38[C(\mathrm{H}) \mathrm{Ph}], 126.56$, $128.72,129.05,133.49[\mathrm{Ph}], 217.93$ [cis-CO], 222.61 [trans-CO], 295.42 [C(carbene)]. MS $m / z(\%): 365$ (12) $\left[\mathrm{M}^{+}\right], 309(7)\left[\mathrm{M}^{+}-2 \mathrm{CO}\right], 281(8)\left[\mathrm{M}^{+}-3 \mathrm{CO}\right], 253$ (21) $\left[\mathrm{M}^{+}-4 \mathrm{CO}\right], 225(100)\left[\mathrm{M}^{+}-5 \mathrm{CO}\right]$.

3.5. Pentacarbonyl[1-(4,5-dihydro-2-methylthiazolium)2-methyl-1-propenyl]chromate (9a) and pentacarbonyl[4,5-dihydro-2-methylthiazole-N]chromium (10a)

When a green solution of $\left[(\mathrm{CO})_{5} \mathrm{Cr}=\mathrm{C}=\mathrm{CMe}_{2}\right]$ (see Section 3.2) is charged at $-45^{\circ} \mathrm{C}$ with $0.36 \mathrm{ml}(0.23$ mmol) of 2-methyl 4,5-dihydrothiazole (8a) the color immediately turns yellow. After stirring the solution for $15 \mathrm{~min}$, it is allowed to warm to r.t. Stirring is continued for $1 \mathrm{~h}$, the volume of the solution reduced in vacuo to 5 and $50 \mathrm{ml}$ of pentane is added. A yellow precipitate forms. The suspension is kept at $-20^{\circ} \mathrm{C}$ for $24 \mathrm{~h}$ and then fritted at r.t. through a $2-\mathrm{cm}$ layer of neutral alumina. The $\mathrm{Al}_{2} \mathrm{O}_{3}$ layer is eluted with $50 \mathrm{ml}$ of pentane. The volume of the combined pentane fractions is reduced to ca. $7 \mathrm{ml}$. The solution is then chromatographed at $-20^{\circ} \mathrm{C}$ on flash silica with pentane$\mathrm{CH}_{2} \mathrm{Cl}_{2}$ mixtures (ratio decreasing from 1:0 to 5:2). The first yellow band contains $\left[\mathrm{Cr}(\mathrm{CO})_{6}\right]$, the second one complex 9a. Removal of the solvent of the second fraction affords $80 \mathrm{mg}\left(7.5 \%\right.$ relative to $\left.\left[\mathrm{Cr}(\mathrm{CO})_{6}\right]\right)$ of 10a. The residue on top of the $\mathrm{Al}_{2} \mathrm{O}_{3}$ layer is dissolved in $80 \mathrm{ml}$ of $\mathrm{CH}_{2} \mathrm{Cl}_{2}$. The solvent is removed in vacuo and the residue dissolved in $8 \mathrm{ml}$ of diethyl ether. The solution is kept at $-20^{\circ} \mathrm{C}$ for $24 \mathrm{~h}$ and then filtered at $-18^{\circ} \mathrm{C}$ over a $6-\mathrm{cm}$ layer of sand/glass wool/sand. The layer is eluted with $8 \mathrm{ml}$ of precooled diethyl ether. The solvent is removed in vacuo to yield $0.56 \mathrm{~g}(11 \%$ relative to $\left.\left[\mathrm{Cr}(\mathrm{CO})_{6}\right]\right)$ of $9 \mathbf{a}$ as a yellow solid. M.p. $108^{\circ} \mathrm{C}$. IR $\left(\mathrm{CH}_{2} \mathrm{Cl}_{2}\right): v(\mathrm{CO})\left(\mathrm{cm}^{-1}\right): 2042 \mathrm{~m}, 1958 \mathrm{w}$, 1911 vs, 1904 vs. ${ }^{1} \mathrm{H}-\mathrm{NMR}\left(\mathrm{CD}_{3} \mathrm{COCD}_{3}\right): \delta 1.54$ and $1.92\left(2 \mathrm{~s}, 3 \mathrm{H}\right.$ each, $\left.\mathrm{C}=\mathrm{CCH}_{3}\right), 2.43\left(\mathrm{~s}, 3 \mathrm{H}, \mathrm{N}=\mathrm{CCH}_{3}\right)$, $3.81\left(\mathrm{t},{ }^{3} J=8.8 \mathrm{~Hz}, 2 \mathrm{H}, \mathrm{SCH}_{2}\right), 4.35\left(\mathrm{dt},{ }^{2} J=12.8\right.$, $\left.{ }^{3} J=8.8 \mathrm{~Hz}, 1 \mathrm{H}, \mathrm{NCH}_{2}\right), 4.94\left(\mathrm{dt},{ }^{2} J=12.8,{ }^{3} J=8.8\right.$ $\left.\mathrm{Hz}, 1 \mathrm{H}, \mathrm{NCH}_{2}\right) .{ }^{13} \mathrm{C}-\mathrm{NMR}\left(\mathrm{CD}_{3} \mathrm{COCD}_{3}\right.$, for the numbering scheme see Fig. 2): $\delta$ 17.62, 20.17 [C(8), C(9)], $25.87[\mathrm{C}(13)], 28.73[\mathrm{C}(11)], 61.85$ [C(12)], 139.14, $161.23[\mathrm{C}(6), \mathrm{C}(7)], 173.85$ [C(10)], 221.35 [cis-CO], 224.44 [trans-CO]. MS $m / z$ (\%): 347 (4) $\left[\mathrm{M}^{+}\right], 319$ (1) $\left[\mathrm{M}^{+}-2 \mathrm{CO}\right], 291$ (1) $\left[\mathrm{M}^{+}-2 \mathrm{CO}\right], 263$ (1) $\left[\mathrm{M}^{+}-\right.$ 3CO], 246 (6) [ $\mathrm{M}^{+}-2$-methyl 4,5-dihydrothiazole], 235 (49) $\left[\mathrm{M}^{+}-4 \mathrm{CO}\right], 218$ (7) $\left[\mathrm{M}^{+}-2\right.$-methyl 4,5-dihydrothiazole-CO], $207(30)\left[\mathrm{M}^{+}-5 \mathrm{CO}\right]$. Anal. Found: $\mathrm{C}, 44.49 ; \mathrm{H}, 3.81 ; \mathrm{N}, 4.33 . \mathrm{C}_{13} \mathrm{H}_{13} \mathrm{CrNO}_{5} \mathrm{~S}$ (347.30). Calc.: C, 44.96; H, 3.77; N, 4.03\%.

10a: Yield: $200 \mathrm{mg}\left(7.5 \%\right.$ relative to $\left.\left[\mathrm{Cr}(\mathrm{CO})_{6}\right]\right)$. M.p. $67^{\circ} \mathrm{C}$. IR (pentane): $v(\mathrm{CO})\left(\mathrm{cm}^{-1}\right): 2067 \mathrm{w}, 1934 \mathrm{vs,}$ 1919 s. ${ }^{1} \mathrm{H}-\mathrm{NMR}\left(\mathrm{CD}_{3} \mathrm{COCD}_{3}\right): \delta 2.46\left(\mathrm{~s}, 3 \mathrm{H}, \mathrm{CH}_{3}\right)$, $3.41\left(\mathrm{t},{ }^{3} J=6.9 \mathrm{~Hz}, 2 \mathrm{H}, \mathrm{SCH}_{2}\right), 4.37\left(\mathrm{t},{ }^{3} J=5.7 \mathrm{~Hz}\right.$, $2 \mathrm{H}, \mathrm{NCH}_{2}$ ).

\subsection{Pentacarbonyl[4,5-dihydro-2-methylthiazole- N]tungsten (11)}

At $-30^{\circ} \mathrm{C} 0.36 \mathrm{ml}(0.23 \mathrm{mmol})$ of 2-methyl 4,5-dihydrothiazole (8a) is added to the highly concentrated solution of the alkyne complex $\left[(\mathrm{CO})_{5} \mathrm{~W}(\mathrm{H}-\mathrm{C} \equiv \mathrm{C}-\mathrm{Ph})\right]$. The solution is stirred and gradually warmed to r.t. The reaction is followed by IR spectroscopy. When the $v(\mathrm{CO})$ absorptions due to the alkyne complexes had disappeared the solvent is removed in vacuo and the reaction products are chromatographed at $-30^{\circ} \mathrm{C}$ on silica gel. First, $\left[\mathrm{Cr}(\mathrm{CO})_{6}\right]$ and imine are eluted with pentane. Next, with pentane- $\mathrm{CH}_{2} \mathrm{Cl}_{2}(10 / 3)$ a yellow band containing the 2,4-dihydrothiazole complex is eluted. Removal of the solvent in vacuo and recrystallization from pentane- $\mathrm{CH}_{2} \mathrm{Cl}_{2}$ give yellow 11. Alternatively, complex $\mathbf{1 1}$ is also obtained from the reaction of $\left[(\mathrm{CO})_{5} \mathrm{~W}(\mathrm{THF})\right]$ with $8 \mathrm{a}$. Yield $0.59 \mathrm{~g}(30 \%$ relative to $\left.\left[\mathrm{Cr}(\mathrm{CO})_{6}\right]\right)$, M.p. $116^{\circ} \mathrm{C}$. IR (pentane): $v(\mathrm{CO})\left(\mathrm{cm}^{-1}\right)$ : $2070 \mathrm{w}, 1932$ vs, $1921 \mathrm{~m} .{ }^{1} \mathrm{H}-\mathrm{NMR}\left(\mathrm{CDCl}_{3}\right): \delta 2.45$ (s, $\left.3 \mathrm{H}, \mathrm{CH}_{3}\right), 3.44\left(\mathrm{t},{ }^{3} \mathrm{~J}=8.6 \mathrm{~Hz}, 2 \mathrm{H}, \mathrm{SCH}_{2}\right), 4.42(\mathrm{dt}$, $J=8.6$ and $\left.1.4 \mathrm{~Hz}, \quad 2 \mathrm{H}, \quad \mathrm{NCH}_{2}\right) .{ }^{13} \mathrm{C}-\mathrm{NMR}$ $\left(\mathrm{CD}_{3} \mathrm{COCD}_{3}\right): \delta 23.97\left[\mathrm{CH}_{3}\right], \quad 32.97,76.01, \quad 181.67$ $[\mathrm{N}=\mathrm{C}], 198.89\left[J_{\mathrm{wC}}=130.5 \mathrm{~Hz}\right.$, cis-CO], 202.67 [trans CO]. MS: $m / z$ (\%). Anal. Found: C, 25.75; H, 1.80; N, 2.78. $\mathrm{C}_{9} \mathrm{H}_{7} \mathrm{NO}_{5} \mathrm{SW}(425.1)$ Calc.: $\mathrm{C}, 25.43 ; \mathrm{H}, 1.66 ; \mathrm{N}$, $3.30 \%$.

\subsection{Pentacarbonyl[1-(4,5-dihydro-2-methyloxazolium)- 2-methyl-1-propenyl]chromate $(\mathbf{9 b})$ and pentacarbonyl- [4,5-dihydro-2-methyloxazole-N]chromium (10b)}

The synthesis from $2.80 \mathrm{~g}(12.8 \mathrm{mmol})$ of $\left[\mathrm{Cr}(\mathrm{CO})_{6}\right]$, $4.76 \mathrm{~g}(25.5 \mathrm{mmol})$ of $\mathrm{C}_{9} \mathrm{~K}_{2}, 1.3 \mathrm{ml}$ of isobutyryl chloride $(12.8 \mathrm{mmol})$, and $0.54 \mathrm{ml}(6.38 \mathrm{mmol})$ of 2-methyl 4,5-dihydrooxazole ( $\mathbf{8 b}$ ) and the purification of the products are carried out analogously to 3.2 and 3.6.

9b: Yellow solid. Yield: $880 \mathrm{mg}(21 \%$ relative to $\left.\left[\mathrm{Cr}(\mathrm{CO})_{6}\right]\right)$. M.p. $108^{\circ} \mathrm{C}$. IR $\left(\mathrm{CH}_{2} \mathrm{Cl}_{2}\right) v(\mathrm{CO})\left(\mathrm{cm}^{-1}\right)$ : 2044 w, 1959 w, 1911 vs, 1900 vs. ${ }^{1} \mathrm{H}-\mathrm{NMR}$ $\left(\mathrm{CD}_{3} \mathrm{COCD}_{3}\right): \delta 1.59$ and $1.91(2 \mathrm{~s}, 3 \mathrm{H}$ each, $\left.\mathrm{C}=\mathrm{CCH}_{3}\right), 2.31\left(\mathrm{~s}, 3 \mathrm{H}, \mathrm{N}=\mathrm{CCH}_{3}\right), 4.07\left(\mathrm{dt},{ }^{2} J={ }^{3} J=8.7\right.$ $\left.\mathrm{Hz}, 1 \mathrm{H}, \mathrm{NCH}_{2}\right), 4.71\left(\mathrm{dt},{ }^{2} J={ }^{3} J=8.7 \mathrm{~Hz}, 1 \mathrm{H}, \mathrm{NCH}_{2}\right)$, $5.05 \quad\left(\mathrm{t}, \quad{ }^{3} \mathrm{~J}=8.7 \quad \mathrm{~Hz}, \quad 2 \mathrm{H}, \quad \mathrm{OCH}_{2}\right) . \quad{ }^{13} \mathrm{C}-\mathrm{NMR}$ $\left(\mathrm{CD}_{3} \mathrm{COCD}_{3}\right.$, for the numbering scheme see Fig. 2$): \delta$ 12.61, 19.99 [C(8), C(9)], 26.13 [C(13)], 52.25 [C(12)], $70.28[\mathrm{C}(11)], 141.57,154.53 \quad[\mathrm{C}(6), \mathrm{C}(7)], 167.54$ [C(10)], 221.81[cis-CO], 224.54 [trans-CO]. MS $m / z(\%)$ : 331 (4) $\left[\mathrm{M}^{+}\right], 303(1)\left[\mathrm{M}^{+}-\mathrm{CO}\right], 275(1)\left[\mathrm{M}^{+}-2 \mathrm{CO}\right]$, 246 (8) $\left[\mathrm{M}^{+}\right.$-2-methyl 4,5-dihydrooxazole], 218 (9) $\left[\mathrm{M}^{+}\right.$- 2-methyl 4,5-dihydrooxazole-CO], $191 \quad$ (25) $\left[\mathrm{M}^{+}-5 \mathrm{CO}\right]$. Anal. Found: C, 47.20; H, 4.09; N, 4.43. $\mathrm{C}_{13} \mathrm{H}_{13} \mathrm{CrNO}_{6}$ (331.21). Calc.: $\mathrm{C}, 47.14 ; \mathrm{H}, 3.96 ; \mathrm{N}$, $4.23 \%$. 
10b: Yellow solid. Yield: $120 \mathrm{mg}(3.4 \%$ relative to $\left.\left[\mathrm{Cr}(\mathrm{CO})_{6}\right]\right)$. M.p. $62^{\circ} \mathrm{C}$. IR $\left(\mathrm{CH}_{2} \mathrm{Cl}_{2}\right): v(\mathrm{CO})\left(\mathrm{cm}^{-1}\right)$ : 2062 w, 1935 vs, 1917 s. ${ }^{1} \mathrm{H}-\mathrm{NMR}\left(\mathrm{CDCl}_{3}\right): \delta 2.15$ (s, $\left.3 \mathrm{H}, \mathrm{CH}_{3}\right), 3.79\left(\mathrm{t},{ }^{3} J=7.9 \mathrm{~Hz}, 2 \mathrm{H}, \mathrm{NCH}_{2}\right), 4.24(\mathrm{t}$, $\left.{ }^{3} J=8.1 \mathrm{~Hz}, 2 \mathrm{H}, \mathrm{OCH}_{2}\right)$. MS $m / z(\%): 277(68)\left[\mathrm{M}^{+}\right]$, 249 (3) $\left[\mathrm{M}^{+}-\mathrm{CO}\right], 221$ (1) $\left[\mathrm{M}^{+}-2 \mathrm{CO}\right], 193(2)\left[\mathrm{M}^{+}\right.$ $-3 \mathrm{CO}$, 165 (22) $\left[\mathrm{M}^{+}-4 \mathrm{CO}\right], 137(100)\left[\mathrm{M}^{+}-5 \mathrm{CO}\right]$.

3.8. Pentacarbonyl $\{2-$ methyl-1-[N-methyl- $N$ (1-methoxy)ethylideneaminium]-1-propenyl chromate (14)

The reaction of $3.20 \mathrm{~g}(14.6 \mathrm{mmol})$ of $\left[\mathrm{Cr}(\mathrm{CO})_{6}\right], 5.44$ g (29.2 mmol) of $\mathrm{C}_{9} \mathrm{~K}_{2}$, and $1.5 \mathrm{ml}$ of isobutyryl chloride $(14.6 \mathrm{mmol})$ with $0.67 \mathrm{ml}(7.3 \mathrm{mmol})$ of $N$ methyl 1-methoxyethylideneamine (13) and the purification of the products are carried out analogously to 3.2 and 3.6. Complex $\mathbf{1 4}$ is obtained in form of a yellow solid. Yield: $0.67 \mathrm{~g}\left(14 \%\right.$ relative to $\left.\left[\mathrm{Cr}(\mathrm{CO})_{6}\right]\right)$. M.p.: $88^{\circ} \mathrm{C}$. IR $\left(\mathrm{CH}_{2} \mathrm{Cl}_{2}\right): v(\mathrm{CO})\left(\mathrm{cm}^{-1}\right): 2039 \mathrm{w}, 1954 \mathrm{w}$, 1909 vs, 1892 vs. ${ }^{1} \mathrm{H}-\mathrm{NMR}\left(\mathrm{CD}_{3} \mathrm{COCD}_{3}\right): \delta 1.43$ and $1.83\left(2 \mathrm{~s}, 3 \mathrm{H}\right.$ each, $\left.\mathrm{C}=\mathrm{C}-\mathrm{CH}_{3}\right), 2.67 \quad(\mathrm{~s}, 3 \mathrm{H}$, $\left.\mathrm{C}\left(\mathrm{OCH}_{3}\right) \mathrm{CH}_{3}\right), 3.47\left(\mathrm{~s}, 3 \mathrm{H}, \mathrm{NCH}_{3}\right), 4.17$ (s, 3H, $\left.\mathrm{OCH}_{3}\right) . \quad{ }^{13} \mathrm{C}-\mathrm{NMR} \quad\left(\mathrm{CD}_{3} \mathrm{COCD}_{3}\right): \quad \delta \quad 13.62, \quad 19.71$ $\left[\mathrm{C}\left(\mathrm{CH}_{3}\right)_{2}\right], 28.83\left[\mathrm{C}\left(\mathrm{OCH}_{3}\right) \mathrm{CH}_{3}\right], 41.00\left[\mathrm{NCH}_{3}\right], 59.36$ $\left[\mathrm{OCH}_{3}\right], 134.26,163.96\left[\mathrm{CrC}, \mathrm{CMe}_{2}\right], 165.36[\mathrm{~N}=\mathrm{C}]$, 222.32 [cis-CO], 225.27 [trans-CO]. MS m/z (\%): 333 (3.3) $\left[\mathrm{M}^{+}\right], 305(0.3)\left[\mathrm{M}^{+}-\mathrm{CO}\right], 2.77(0.3)\left[\mathrm{M}^{+}-\right.$ $2 \mathrm{CO}], 246$ (8.54) $\left[\mathrm{M}^{+}\right.$- methyl methoxyethylideneamine $], 221 \quad$ (2.44) $\quad\left[\mathrm{M}^{+}-4 \mathrm{CO}\right], \quad 193 \quad$ (16.34) $\left[\mathrm{M}^{+}-5 \mathrm{CO}\right]$. Anal. Found: $\mathrm{C}, 44.75 ; \mathrm{H}, 4.43 ; \mathrm{N}, 4.16$. $\mathrm{C}_{13} \mathrm{H}_{15} \mathrm{CrNO}_{6}$ (333.26) Calc.: C, 46.85; H, 4.54; N, $4.20 \%$.

\subsection{Pentacarbonyl $\{1-[N-$ methyl-N-(1-methoxy)-} ethylideneaminium]-2,2-diphenylethenyl\}tungsten (15)

A green solution of $0.25 \mathrm{~g}(0.5 \mathrm{mmol})$ of complex 12 in $4 \mathrm{ml}$ of $\mathrm{CH}_{2} \mathrm{Cl}_{2}$ is charged at $-20^{\circ} \mathrm{C}$ with $0.043 \mathrm{~g}$ (0.5 mmol) of $N$-methyl 1-methoxyethylideneamine (13) in $2 \mathrm{ml}$ of $\mathrm{CH}_{2} \mathrm{Cl}_{2}$. The solution is stirred and allowed to warm to r.t. The progress of the reaction is followed by IR spectroscopy. After ca. $4-5 \mathrm{~h}$ the reaction is complete. Then, $150 \mathrm{ml}$ of precooled pentane is added and a yellow precipitate formed. The suspension is fritted over $\mathrm{Na}_{2} \mathrm{SO}_{4}$ and the solid washed $3 \times$ with 50 $\mathrm{ml}$ of pentane each. The adduct on top of the $\mathrm{Na}_{2} \mathrm{SO}_{4}$ layer is dissolved in $\mathrm{CH}_{2} \mathrm{Cl}_{2}$. The solvent is removed in vacuo to give $\mathbf{1 5}$ as a slightly yellow powder. Yield: 0.18 g $(61 \%$ relative to 12$)$. M.p. (dec.) $28^{\circ} \mathrm{C}$. IR $\left(\mathrm{CH}_{2} \mathrm{Cl}_{2}\right)$ : $v(\mathrm{CO})\left(\mathrm{cm}^{-1}\right): 2053 \mathrm{~m}, 1961 \mathrm{w}, 1910 \mathrm{vs}, 1900 \mathrm{sh}, 1875$ sh. ${ }^{1} \mathrm{H}-\mathrm{NMR}\left(\mathrm{CD}_{3} \mathrm{COCD}_{3},-50^{\circ} \mathrm{C}\right): \delta 2.46(\mathrm{~s}, 3 \mathrm{H}$, $\left.\mathrm{CCH}_{3}\right), 3.28\left(\mathrm{~s}, 3 \mathrm{H}, \mathrm{NCH}_{3}\right), 4.36\left(\mathrm{~s}, 3 \mathrm{H}, \mathrm{OCH}_{3}\right), 7.1-$ $7.33(\mathrm{~m}, 10 \mathrm{H}, \mathrm{Ph}) .{ }^{13} \mathrm{C}-\mathrm{NMR}\left(\mathrm{CD}_{3} \mathrm{COCD}_{3},-50^{\circ} \mathrm{C}\right): \delta$ $13.22\left[\mathrm{CCH}_{3}\right], 41.17\left[\mathrm{NCH}_{3}\right], 59.50\left[\mathrm{OCH}_{3}\right], 126.78$, $126.84,127.79,128.53,128.74,130.13[\mathrm{Ph}], 147.26$,
$148.79[\mathrm{Ph}], 143.57,163.67\left[\mathrm{WC}, \mathrm{CPh}_{2}\right], 165.63[\mathrm{~N}=\mathrm{C}]$, 200.86 [cis-CO], 206.53 [trans-CO]. MS $\mathrm{m} / z$ (\%): 589 (24) $\left[\mathrm{M}^{+}\right], 561(19)\left[\mathrm{M}^{+}-\mathrm{CO}\right], 533(33)\left[\mathrm{M}^{+}-2 \mathrm{CO}\right]$, 505 (100) $\left[\mathrm{M}^{+}-3 \mathrm{CO}\right], 418$ (23) $\left[\mathrm{M}^{+}-3 \mathrm{CO}-\right.$ methyl methoxyethylideneamine], 266 (92) $\left[\mathrm{M}^{+}-\mathrm{W}(\mathrm{CO})_{5}\right]$, 193 (16.34) $\left[\mathrm{M}^{+}-5 \mathrm{CO}\right.$. Anal. Found: $\mathrm{C}, 46.38 ; \mathrm{H}$, 3.49; N, 2.09. $\mathrm{C}_{23} \mathrm{H}_{19} \mathrm{NO}_{6} \mathrm{~W}(589.25)$ Calc.: C, 46.92; H, $3.25 ; \mathrm{N}, 2.37 \%$.

\subsection{Pentacarbonyl[(isopropyl( $N$-xanthylideneamino)- carbene]chromium (17)}

The reaction of $1.65 \mathrm{~g}(7.5 \mathrm{mmol})$ of $\left[\mathrm{Cr}(\mathrm{CO})_{6}\right], 2.8 \mathrm{~g}$ (15 mmol) of $\mathrm{C}_{9} \mathrm{~K}_{2}$, and $0.8 \mathrm{ml}$ of isobutyryl chloride (7.5 mmol) with $0.74 \mathrm{ml}(4.9 \mathrm{mmol})$ of xanthylideneamine (16) is carried out analogously to 3.2. The color of the suspension immediately changes from dark green to red. After stirring for $15 \mathrm{~min}$, the solvent is removed in vacuo. The oily residue is chromatographed at $-20^{\circ} \mathrm{C}$ on flash silica with pentane $-\mathrm{CH}_{2} \mathrm{Cl}_{2}$ mixtures (ratio decreasing from 1:0 to 7:1). First, a green fraction is eluted. The second fraction (orange) is collected containing 17. Removal of the solvent in vacuo at r.t. affords complex $\mathbf{1 7}$ as an orange solid. Yield: 560 $\mathrm{mg}\left(17 \%\right.$ relative to $\left.\left[\mathrm{Cr}(\mathrm{CO})_{6}\right]\right)$. M.p.: $113^{\circ} \mathrm{C}$. IR $\left(\mathrm{CH}_{2} \mathrm{Cl}_{2}\right): v(\mathrm{CO})\left(\mathrm{cm}^{-1}\right): 2051 \mathrm{~m}, 1967 \mathrm{w}, 1925$ vs. ${ }^{1} \mathrm{H}-\mathrm{NMR}\left(\mathrm{CDCl}_{3}\right): \delta 1.24\left(\mathrm{~d},{ }^{3} \mathrm{~J}=6.7 \mathrm{~Hz}, 6 \mathrm{H}, \mathrm{CH}_{3}\right)$, 3.46 (hept, ${ }^{3} J=6.7 \mathrm{~Hz}, 1 \mathrm{H}, \mathrm{CH} \mathrm{Me}_{2}$ ), 7.3-7.4 (m, 8H, $\mathrm{Ph}) .{ }^{13} \mathrm{C}-\mathrm{NMR} \quad\left(\mathrm{CDCl}_{3}\right): \quad \delta \quad 20.96 \quad\left[\mathrm{CH}_{3}\right], 49.36$ $\left[\mathrm{CMe}_{2} \mathrm{H}\right], 111.58,117.92,125.00,125.60,133.29[\mathrm{Ph}]$, $152.92[\mathrm{~N}=\mathrm{C}], 219.34$ [cis-CO], 223.29 [trans $-\mathrm{CO}$, 225.45 [C(carbene)]. MS m/z (\%): 441 (6) $\left[\mathrm{M}^{+}\right], 413$ (2.5) $\left[\mathrm{M}^{+}-\mathrm{CO}\right], 385(1)\left[\mathrm{M}^{+}-2 \mathrm{CO}\right], 357(2)\left[\mathrm{M}^{+}-\right.$ $3 \mathrm{CO}], 329$ (13) $\left[\mathrm{M}^{+}-4 \mathrm{CO}\right], 301$ (49) $\left[\mathrm{M}^{+}-5 \mathrm{CO}\right]$. Anal. Found: $\mathrm{C}, 59.53 ; \mathrm{H}, 3.52 ; \mathrm{N}, 3.59 . \mathrm{C}_{22} \mathrm{H}_{14} \mathrm{CrNO}_{6}$ (440.02). Calc.: C, 60.00; H, 3.21; N, 3.18\%.

\subsection{X-ray structural analyses of $\mathbf{6}, \mathbf{9 a}$ and $\mathbf{1 1}$}

6: $\mathrm{C}_{17} \mathrm{H}_{15} \mathrm{CrNO}_{5}$, molecular mass (365.3), crystal size $0.35 \times 0.35 \times 0.35 \mathrm{~mm}^{3}$ (obtained by recrystallization from diethyl ether); crystal system triclinic, space group $P \overline{1}, a=8.622(3), \quad b=9.319(3), c=12.225(4) \AA, \alpha=$ $89.49(2), \quad \beta=88.39(3), \gamma=62.76(2)^{\circ} ; \quad V=872.6(5) \AA^{3}$, $Z=2, D_{\text {calc }}=1.390 \mathrm{~g} \mathrm{~cm}^{-3}, \lambda\left(\mathrm{Mo}-\mathrm{K}_{\alpha}\right)=0.71073 \AA$, $F(000) 376$; Wyckoff scan, $2 \Theta$ range $4.0-54.0^{\circ}$, scan rate variabel $4.0-30.0^{\circ} \mathrm{min}^{-1}$ in $\omega ; 4035$ independent reflections, 3282 reflection with $F>4 \sigma(F) ; 217$ refined parameters; $R=0.0377, w R=0.0443$. Largest difference peak (hole): +0.33 e $\AA^{-3}\left(-0.30\right.$ e $\left.\AA^{-3}\right)$.

9a: $\mathrm{C}_{13} \mathrm{H}_{13} \mathrm{CrNO}_{5} \mathrm{~S}$, molecular mass (347.3), crystal size $0.25 \times 0.25 \times 0.25 \mathrm{~mm}^{3}$ (obtained by recrystallization from diethyl ether); crystal system triclinic, space group $P \overline{1}, a=8.936(3), b=9.470(3), c=9.888(3) \AA$, $\alpha=89.82(2), \quad \beta=71.76(2), \gamma=75.32(1)^{\circ} ; \quad V=767.3(4)$ $\AA^{3}, Z=2, D_{\text {calc }}=1.503 \mathrm{~g} \mathrm{~cm}^{-3}, \lambda\left(\mathrm{Mo}-\mathrm{K}_{\alpha}\right)=0.71073$ 
$\AA$, $F(000)$ 356; Wyckoff scan, $2 \Theta$ range $4.0-54.0^{\circ}$, scan rate variabel $4.0-30.0^{\circ} \mathrm{min}^{-1}$ in $\omega ; 3352$ independent reflections, 2527 reflection with $F>4 \sigma(F)$; 190 refined parameters; $R=0.0561, w R=0.0611$. Largest difference peak (hole): +0.87 e $\AA^{-3}(-0.53$ e $\AA^{-3}$ ).

11: $\mathrm{C}_{9} \mathrm{H}_{7} \mathrm{NO}_{5} \mathrm{SW}$, molecular mass (425.1), crystal size $0.28 \times 0.28 \times 0.28 \mathrm{~mm}^{3}$ (obtained by recrystallization from pentane); crystal system monoclinic, space group $P 2_{1} / c, a=9.648(7), b=11.436(8), c=12.155(12)$ $\AA, \quad \beta=106.53(9) ; \quad V=1285.6(17) \AA^{3}, Z=4, D_{\text {calc }}=$ $2.196 \mathrm{~g} \mathrm{~cm}^{-3}, F(000)$ 792; adaptive $\omega$ scan, $\Theta$ range $2.2-26.99^{\circ}$, scan rate variabel $4.0-30.0^{\circ} \mathrm{min}^{-1} ; 3352$ independent reflections, 2084 reflection with $\sigma>2 \sigma(I)$; 154 refined parameters; $R=0.0344, \quad w R_{2}=0.0782$. Largest difference peak (hole): +0.998 e $\AA^{-3}$ ($1.245 \mathrm{e}^{-3}$ ).

The measurements were performed at $-44^{\circ} \mathrm{C}(6)$, $-34^{\circ} \mathrm{C}(\mathbf{9 a}),-35^{\circ} \mathrm{C}(\mathbf{1 1})$ with a crystal mounted in a glass capillary on a Siemens P4 diffractometer (graphite monochromator, $\mathrm{Mo}-\mathrm{K}_{\alpha}$ radiation, $\lambda=$ $0.71073 \AA$ ).

The structures were solved by Patterson methods (6, 9a) or by direct methods (11) using the SHELXTL PLUS (VMS) program package. The positions of the hydrogen atoms were calculated by assuming ideal geometry $\left(d_{\mathrm{C}-\mathrm{H}}=0.96 \AA\right)$, and their coordinates were refined together with those of the attached $\mathrm{C}$ atoms as 'riding model'. The positions of all other atoms were refined anisotropically by the full-matrix least-squares method.

\section{Supplementary material}

Crystallographic data for the structural analysis have been deposited with the Cambridge Crystallographic Data Centre, CCDC no. 144590 for compound 6, CCDC no. 144591 for compound 9a and CCDC no. 144589 for compound 11. Copies of this information may be obtained free of charge from The Director, CCDC, 12 Union Road, Cambridge CB2 1EZ, UK (Fax: + 44-1223-336033; e-mail: deposit@ ccdc.cam.ac.uk or www: http://www.ccdc.cam.ac.uk).

\section{Acknowledgements}

Support of these investigations by the Deutscher Akademischer Austauschdienst (grant for M.M. AbdElzaher), the Volkswagen-Stiftung and the Fonds der Chemischen Industrie is gratefully acknowledged.

\section{References}

[1] A.G.M. Barrett, J. Mortier, M. Sabat, M.A. Sturgess, Organometallics 7 (1988) 2553.

[2] (a) A.G.M. Barrett, M.A. Sturgess, Tetrahedron Lett. 27 (1986) 3811. (b) A.G.M. Barrett, M.A. Sturgess, J. Org. Chem. 52 (1987) 3940.

[3] M.R. Terry, L.A. Mercando, C. Kelley, G.L. Geoffroy, P. Nombel, N. Lugan, R. Mathieu, R.L. Ostrander, B.E. OwensWaltermire, A.L. Rheingold, Organometallics 13 (1994) 843.

[4] H. Fischer, A. Schlageter, W. Bidell, A. Früh, Organometallics 10 (1991) 389

[5] K. Weiss, E.O. Fischer, J. Müller, J. Chem. Ber. 107 (1974) 3548.

[6] A.G.M. Barrett, C.P. Brock, M.A. Sturgess, Organometallics 4 (1985) 1903.

[7] M.M. Abd-Elzaher, H. Fischer, J. Organomet. Chem. 588 (1999) 235.

[8] M.M. Abd-Elzaher, T. Froneck, G. Roth, V. Gvozdev, H. Fischer, J. Organomet. Chem. 599 (2000) 288.

[9] H. Fischer, F. Leroux, G. Roth, R. Stumpf, Organometallics 15 (1996) 3723.

[10] M.A. Schwindt, T. Lejon, L.S. Hegedus, Organometallics 9 (1990) 2814.

[11] H. Fischer, C.C. Karl, G. Roth, Chem. Ber. 129 (1996) 615.

[12] F.H. Allen, O. Kennard, D.G. Watson, L. Brammer, A.G. Orpen, R. Taylor, J. Chem. Soc. Perkin Trans. II (1987) S1.

[13] U. Schubert, in: K.H. Dötz, H. Fischer, P. Hofmann, F.R. Kreissl, U. Schubert, K. Weiss (Eds.), Transition Metal Carbene Complexes, Verlag Chemie, Weinheim, 1983, p. 73.

[14] H. Fischer, H.-P. Volkland, A. Früh, R. Stumpf, J. Organomet. Chem. 491 (1995) 267.

[15] For the IR and NMR spectra of other alkylideneaminocarbene complexes of chromium and tungsten see: (a) H. Fischer, S. Zeuner, K. Ackermann, U. Schubert, J. Organomet. Chem. 263 (1984) 201. (b) H. Fischer, R. Märkl, Chem. Ber. 118 (1985) 3683. (c) F. Seitz, H. Fischer, J. Riede, J. Organomet. Chem. 287 (1985) 87. (d) C.K. Murray, B.P. Warner, V. Dragisich, W.D. Wulff, Organometallics 9 (1990) 3142.

[16] H. Bredereck, F. Effenberger, E. Hensllit, Chem. Ber. 98 (1965) 2734. 